
RESEARCH AND DEVELOPMENT

\author{
http://journal.unnes.ac.id/sju/index.php/higeia
}

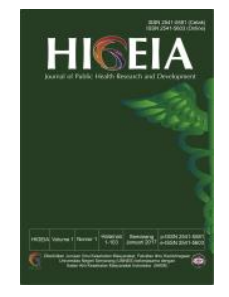

\title{
FAKTOR KEJADIAN OBESITAS SENTRAL PADA USIA DEWASA
}

\section{Nimas Puspitasari ${ }^{\circledR}$}

Epidemiologi dan Biostatistika, Jurusan Ilmu Kesehatan Masyarakat, Fakultas Ilmu Keolahragaan, Univeritas Negeri Semarang

\section{Info Artikel}

Sejarah Artikel:

Diterima Februari 2018

Disetujui Maret 2018

Dipublikasikan April

2018

Keywords:

Risk factors, Central obesity,

Adult

\begin{abstract}
Abstrak
Prevalensi obesitas sentral di Kota Semarang sebesar 36,3\% pada tahun 2013. Proporsi kejadian obesitas sentral di Kelurahan Plalangan pada tahun 2013 sebanyak 61,7\%. Usia dewasa merupakan faktor risiko dari obesitas sentral, prevalensi obesitas sentral tahun 2013 pada kelompok usia 25-34 tahun (22,9\%) dan 35-44 tahun (33,5\%). Penelitian ini dilakukan pada bulan September-Oktober tahun 2017. Tujuan penelitian ini untuk mengetahui faktor-faktor yang berhubungan dengan kejadian obesitas sentral pada usia dewasa. Jenis penelitian ini adalah analitik observasional dengan desain cross sectional yang melibatkan 102 sampel. Instrument penelitian yang digunakan adalah lembar kuesioner dan alat ukur. Analisis data mengunakan uji Chi-square. Hasil penelitian menunjukan bahwa nilai $p$ value jenis kelamin $(p=0,001)$, tingkat pengetahuan $(p=0,159)$, tingkat pendidikan $(p=0,024)$, jenis pekerjaan $(p=0,658)$, status kawin $(p=0,144)$, riwayat keturunan $(p=0,003)$, aktivitas fisik $(p=0,000)$, status merokok $(p=0,409)$, dan intake kalori $(p=0,001)$. Simpulan penelitian ini adalah terdapat hubungan antara jenis kelamin, tingkat pendidikan, riwayat keturunan, aktivitas fisik, dan intake kalori dengan kejadian obesitas sentral pada usia dewasa.
\end{abstract}

\begin{abstract}
The prevalence of central obesity in Semarang City was 36.3\% in 2013. The proportion of central obesity in Kelurahan Plalangan in 2013 was $61.7 \%$. Adult age was a risk factor for central obesity, the prevalence of central obesity in 2013 in the 25-34 years age group (22.9\%) and 35-44 years (33.5\%). This research was conducted in September-October 2017. The purpose of this study to determine the factors associated with the incidence of central obesity at adult. The type of this study was observational analytic with cross sectional design involving 102 samples. The research instruments used questionnaire and measuring instrument. Data analysis used Chi-square test. The results showed that $p$ value of sex $(p=0,001)$, knowledge level $(p=0,159)$, education level $(p=0,024)$, job type $(p=0,658)$, marital status $(p=0,144)$, physical activity $(p=0,003)$, physical activity $(p=0,000)$, smoking status $(p=0,409)$, and caloric intake $(p=0,001)$. The conclusions of this study there were relationship between sex, education level, hereditary history, physical activity, and caloric intake with central obesity occurrence in adult.
\end{abstract}

Alamat korespondensi: Gedung F5 Lantai 2 FIK Unnes

E-mail: nimaspuspitasari96@gmail.com 


\section{PENDAHULUAN}

Obesitas sentral yaitu obesitas yang menyerupai apel, yaitu lemak disimpan pada bagian pinggang dan ronga perut. Penumpukan lemak ini diakibatkan oleh jumlah lemak berlebih pada jaringan lemak subkutan dan lemak viseral perut. penumpukan lemak pada jaringan lemak viseral merupakan bentuk dari tidak berfungsinya jaringan lemak subkutan dalam menghadapi kelebihan energi akibat konsumsi lemak berlebih.

Obesitas sentral dapat diukur menggunakan metode rasio lingkar pinggang dan pinggul (RLPP). Batasan untuk menyatakan status obesitas sentral untuk lakilaki dengan LP $>90 \mathrm{~cm}$ dan perempuan LP > $80 \mathrm{~cm}$. Obesitas sentral salah satu penyebab terjadinya penyakit-penyakit degeneratif, antara lain diabetes millitus tipe 2, dislipidemia, penyakit jantung koroner, hipertensi, kanker dan sindrom metabolik (Tchernof \& Despres, 2013).

Kematian di dunia akibat obesitas, sebanyak 3,4 juta orang dewasa meninggal setiap tahunnya. Dilaporkan $44 \%$ kematian terjadi akibat diabetes, $23 \%$ dari penyakit jantung iskemik dan 7-41 \% adalah akibat kanker (WHO, 2013). Berdasarkan Sample Registration Survey Kemenkes RI, menunjukkan penyakit jantung koroner merupakan penyebab kematian terbesar kedua di Indonesia dengan presentase sebesar $12,9 \%$ setelah stroke $(21,1 \%)$ dan kemudian diikuti oleh diabetes mellitus dengan presentase sebesar 6,7\%. Berdasarkan penelitian Veghari (2012), Prevalensi obesitas sentral sebanyak $35,4 \%$ terjadi pada wanita dan daerah perkotaan. Sedangkan prevalensi obesitas sentral di Gorgan (Iran utara) adalah $39,1 \%$ dan $21,2 \%$ di Ahvas (Iran Selatan), sementara itu dilaporkan menjadi $9,7 \%$ di seluruh Iran.

Prevalensi obesitas sentral di Indonesia, menurut Riset Kesehatan Dasar (Riskesdas) tahun 2007 melaporakan 18,8\% penduduk usia 15 tahun keatas mengalami obesitas sentral. Sedangkan berdasarkan Riskesdas tahun 2013 prevalensi obesitas sentral meningkat menjadi
26,6\% pada usia 15 tahun keatas. Prevalensi obesitas sental pada laki-laki (11,3\%) dan pada perempuan $(42,1 \%)$. Obesitas sentral pada usia dewasa di Indonesia tahun 2007 mengalami peningkatan di tahun 2013 yaitu pada kelompok usia 25-34 tahun (17,9\%) menjadi $(26,1 \%), 35$ 44 tahun $(24,4 \%)$ menjadi $(35,1 \%)$.

Obesitas sentral di Jawa Tengah pada penduduk usia 15 tahun keatas berdasarkan Riskesdas Jawa Tengah tahun 2007 sebesar 21,1\% dan meningkat pada tahun 2013 yaitu sebesar $24,7 \%$. Obesitas sentral pada usia dewasa di Jawa Tengah tahun 2007 mengalami peningkatan di tahun 2013 yaitu pada kelompok usia 25-34 tahun (16,7\%) menjadi (22,9\%), 3544 tahun (22,8\%) menjadi (33,5\%). Kota Semarang termasuk dalam 3 (tiga) kota/kabupaten yang mengalami obesitas sentral tertinggi yaitu sebesar 36,3\% (Kemeskes RI, 2013).

Seiring dengan bertambahnya usia, prevalensi obesitas sentral mengalami peningkatan. Peningkatan usia akan mengingkatkan kandungan lemak tubuh total, terutama distribusi lemak pusat. Prevalensi obesitas sentral meningkat sampai dengan usia 44 tahun dan menurun kembali pada usia 45-54 tahun. Prevalensi obesitas sentral ditemukan lebih tinggi pada sampel dengan usia lebih tua. Pada usia lebih tua terjadi penurunan massa otot dan perubahan beberapa jenis hormon yang memicu penumpukan lemak perut.

Obesitas sentral dapat menyebabkan gangguan kesehatan, seperti diabetes mellitus tipe II, displidemia, penyakit kardiovaskular, hipertensi, kanker, sleep apnea, dan sindrom metabolik (Tchernof \& Despres, 2013). Selain itu obesitas sentral dapat menyebabkan resistensi insulin. Peningkatan resistensi insulin terjadi bersamaan dengan peningkatan kadar lemak dalam tubuh.

Hendrik L. Blum menyatakan faktorfaktor yang mempengaruhi kesehatan individu berdasarkan besarnya pengaruh secara berurutan. Obesitas sentral disebabkan oleh adanya beberapa faktor seperti faktor lingkungaan, faktor perilaku, dan faktor genetik. Faktor lingkungan sebagai komponen yang 
mempunyai pengaruh terhadap kesehatan seseorang dimaknai sebagai suatu hal yang dapat mendorong sikap seseorang dalam mengonsumi makanan sehari-hari yang kemudian akan berdampak pada terjadinya obesitas sentral pada individu. Faktor lingkungan tersebut ditinjau dari faktor lingkungan sosial dan budaya seseorang. Faktor lingkungan pula meliputi penegeluaran perkapita individu, pekerjaan, usia, tingkat pendidikan, tingkat pengetahuan, status kawin, dan jenis kelamin.

Faktor yang berikutnya yang mempengaruhi derajat kesehatan seseorang adalah faktor perilaku. Perilaku yang meningkatkan kesehatan secara komprehensif mencakup kegiatan seperti olahraga teratur, diet seimbang, mengambil tindakan pencegahan keselamatan, tidur yang cukup, perilaku tidak merokok, tidak teradiksi alkohol. Faktor selanjutnya adalah faktor keturunan/ genetik. Keturunan (genetik) merupakan faktor yang telah ada dalam diri manusia yang dibawa sejak lahir, misalnya dari golongan penyakit keturunan seperti diabetes mellitus dan asma bronehial.

Kelurahan Plalangan adalah salah satu desa yang berada di Kecamatan Gunungpati, Kota Semarang. Kelurahan Plalangan mempunyai luas 2,69 km2 yang terdiri dari 19 RT dan 6 RW. Mata pencarian penduduknya sebagian besar adalah petani dan buruh industri. Menurut penelitian Chaput \& Treamblay (2009), data populasi pekerja dari negara-negara di dunia yang perekonomiannya ditunjang oleh sektor industri yang mayoritas memiliki jam kerja yang panjang dan aktivitas pekerja rendah secara signifikan dapat mengubah berat badan pekerja yang semula normal menjadi overweight dan obesitas. Hasil tersebut sejalan dengan penelitian Erliyani (2012) yang melaporkan bahwa proporsi obesitas pada buruh prabik rokok di Kudus (Jawa tengah) dengan usia 3040 tahun sebesar 29,1\%. Kejadian obesitas pada buruh yang diteliti tidak pernah berolahraga, memiliki tingkat aktivitas fisik yang ringan dan memiliki pola konsumsi yang tidak teratur. Proporsi obesitas sentral di Kelurahan
Plalangan, Gunungpati sebesar $61,7 \%$ pada wanita dewasa (Listiyana, 2013).

Berdasarkan uraian tersebut, penulis tertarik melakukan penelitian mengenai faktorfaktor yang mempengaruhi kejadian obesitas sentral pada usia dewasa di Kelurahan Plalangan, Kecamatan Gunungpati, Kota Semarang. Tujuan penelitian ini adalah untuk mengetahui faktor-faktor yang mempengaruhi kejadian obesitas sentral pada usia dewasa di Kelurahan Plalangan, Kecamatan Gunungpati, Kota Semarang.

\section{METODE}

Penelitian ini menggunakan metode penelitian analitik observasional dengan desain penelitian cross sectional. Populasi dalam penelitian ini adalah masyarakat usia dewasa di Kelurahan Plalangan, Kecamatan Gunungpati, Kota Semarang yang berjumlah 1181 orang. Kriteria inklusi dalam sampel penelitian ini adalah a) bersedia menjadi responden; b) responden berusia 26-45 tahun. Sedangkan kriteria eksklusi dalam sampel penelitian ini adalah a) hamil; b) sedang beraktivitas atau bekerja yang tidak bisa diganggu.

Besar sampel minimal dalam penelitian ini mengunakan rumus Slovin dan ditambah $10 \%$ untuk mengantisipasi kemungkinan subjek terpilih yang drop out, dari hasil perhitungan sampel didapatkan besar sampel sebanyak 104 responden. Teknik pengambilan sampel dengan menggunakan Cluster sampling dimana sampel dipilih secara acak pada kelompok individu dalam populasi yang terjadi secra alamiah. Kelurahan Plalangan terdiri dari 6 RW dengan Jumlah 19 RT. Pemilihan sampel ditentukan secara cluster berdasarkan RW, maka jumlah cluster yang diambil 104/6 = 17,3. Setelah di cluster didapatkan setiap RW diambil 17 - 18 responden untuk manjadi sampel.

Instrumen pada penelitian ini adalah kuesioner dan pita ukur. Teknik pengumpulan data dilakukan dengan pengukuran lingkar perut dengan pita ukur, metode wawancara dengan kuesioner dan dokumentasi. Hasil pengukuran lingkar perut yang dilakukan untuk 
mengetahui kejadian obesitas sentral. Metode wawancara dengan kuesioner dilakukan untuk mengetahui jenis kelamin, tingkat pengetahuan, tingkat pendidikan, jenis pekerjaan, status kawin, riwayat keturunan, aktivitas fisik, status merokok, dan intake kalori. Sedangkan metode dokumentasi dalam penelitian ini bertujuan sebagai dokumen pelengkap berupa foto selama kegiatan penelitian berlangsung.

Sumber data dalam penelitian ini diperoleh dari data primer dan sekunder. Data primer yang diperoleh dari penelitian ini berasal dari hasil pengukuran dan pengisian kuesioner oleh responden secara langsung untuk memperoleh data terkait dengan jenis kelamin, tingkat pengetahuan, tingkat pendidikan, jenis pekerjaan, status kawin, riwayat keturunan, aktivitas fisik, status merokok, dan intake kalori. Data sekunder diperoleh dari WHO, Riset Kesehatan Dasar Indonesia Tahun 2013, Riset Kesehtan Dasar Jawa Tengah Tahun 2013, dan Puskesmas Gunungpati. Teknik pengolahan data dalam penelitian ini terdiri dari a) editing (pemeriksaan data); b) coding (pemeriksaan kode); c) entry (memasukan kode jawaban); d) cleaning (pengecekan kembali data).

Analisis data dilakukan dalam penelitian ini menggunakan jenis analisis univariat dan bivariat. Uji statistik pada penelitian ini menggunakan uji Chi-square dan uji Fisher. Variabel yang menggunakan uji Chi-squre adalah jenis kelamin, tingkat pengetahuan, tingkat pekerjaan, riwayat keturunan, aktivitas fisik, status merokok, dan intake kalori. Sedangkan variabel yang menggunakan uji Fisher adalah staus kawin.

\section{HASIL DAN PEMBAHASAN}

Tabel 1. menunjukan distribusi frekuensi variabel bebas dan terikat atau analisis univariat. Dari 102 responden dapat diketahui bahwa responden yang mengalami obesitas sentral sebanyak 69 orang $(67,6 \%)$ sedangkan responden yang tidak mengalami obesitas sentral sebanyak 33 orang $(32,4 \%)$. Responden dengan jenis kelamin perempuan sebanyak 62 orang $(60,8 \%)$ sedangan laki-laki sebanyak 40 orang $(39,2 \%)$. Responden yang memiliki tingkat pengetahuan rendah sebanyak 52 orang (51,0\%), sedangkan responden yang memiliki tingkat pengetahuan tinggi sebanyak 50 orang (49,0\%). Responden yang memiliki tingkat pendidikan dasar sebanyak 52 orang $(51,0 \%)$, sedangkan responden yang memiliki tingkat pendidikan lanjut sebanyak 50 orang (49,0\%). Responden yang tidak bekerja sebanyak 26 orang $(25,5 \%)$, sedangkan responden yang bekerja sebanyak 76 orang $(74,5 \%)$. Responden yang sudah kawin sebanyak 93 orang $(91,2 \%)$, sedangkan responden yang belum kawin sebanyak 9 orang $(8,8 \%)$. Responden dengan keturunan kegemukan sebanyak 41 orang $(40,2 \%)$,sedangkan responden yang tidak memi-

Tabel 1. Distribusi Variabel yang Berhubungan dengan Kejadian Obesitas Sentral pada Usia dewasa di Kelurahan Plalangan, Kecamatan Gunungpati, Kota Semarang Tahun 2017

\begin{tabular}{|c|c|c|c|}
\hline \multirow{2}{*}{ No } & \multirow{2}{*}{ Variabel } & \multicolumn{2}{|c|}{ Frekuensi } \\
\hline & & $\mathrm{N}$ & $\%$ \\
\hline \multirow[t]{3}{*}{1} & Obesitas Sentral & & \\
\hline & $\mathrm{Ya}$ & 69 & 67,6 \\
\hline & Tidak & 33 & 32,4 \\
\hline \multirow[t]{3}{*}{2} & Jenis Kelamin & & \\
\hline & Perempuan & 62 & 60,8 \\
\hline & Laki-laki & 40 & 39,2 \\
\hline \multirow[t]{3}{*}{3} & Tingkat Pengetahuan & & \\
\hline & Rendah & 52 & 51,0 \\
\hline & Tinggi & 50 & 49,0 \\
\hline \multirow[t]{3}{*}{4} & Tingkat Pendidikan & & \\
\hline & Pendidikan dasar & 52 & 51,0 \\
\hline & Pendidikan lanjut & 50 & 49,0 \\
\hline \multirow[t]{3}{*}{5} & Jenis Pekerjaan & & \\
\hline & Tidak bekerja & 26 & 25,5 \\
\hline & Bekerja & 76 & 74,5 \\
\hline \multirow[t]{3}{*}{6} & Status Kawin & & \\
\hline & Sudah kawin & 93 & 91,2 \\
\hline & Belum kawin & 9 & 8,8 \\
\hline \multirow[t]{3}{*}{7} & Riwayat Keturunan & & \\
\hline & Ada & 41 & 40,2 \\
\hline & Tidak ada & 61 & 59,8 \\
\hline \multirow[t]{3}{*}{8} & Aktivitas Fisik & & \\
\hline & Rendah-sedang & 66 & 64,7 \\
\hline & Tinggi & 36 & 35,3 \\
\hline \multirow[t]{3}{*}{9} & Status Merokok & & \\
\hline & Merokok & 33 & 32,4 \\
\hline & Tidak merokok & 69 & 67,5 \\
\hline \multirow[t]{3}{*}{10} & Intake Kalori & & \\
\hline & Tinggi & 51 & 50,0 \\
\hline & Rendah & 51 & 50,0 \\
\hline
\end{tabular}


liki riwayat keturunan kegemukan sebanyak 61 orang $(59,8 \%)$. Responden yang sebanyak 93 orang $(91,2 \%)$, sedangkan responden yang belum kawin sebanyak 9 orang $(8,8 \%)$. Responden yang memiliki riwayat memiliki aktivitas fisik ringan-sedang sebanyak 66 orang $(64,7 \%)$, sedangkan responden yang memiliki aktivitas berat sebanyak 36 orang $(35,3 \%)$. Responden yang merokok sebanyak 33 orang $(32,4 \%)$, sedangkan responden yang tidak merokok sebanyak 69 orang (69,6\%). Responden dengan intake kalori tinggi sebanyak 51 orang $(50,0 \%)$ dan intake kalori rendah sebanyak 51 orang $(50,0 \%)$.

Tabel 2 menunjukan analisis bivariat yakni analisis hubungan antara variabel bebas dan variabel terikat. Berdasarkan hasil penelitian diketahui bahwa dari 62 responden perempuan, ada 50 orang $(80,6 \%)$ yang mengalami obesitas sentral dan 12 orang
$(19,4 \%)$ yang tidak mengalami obesitas sentral. Sedangkan dari 40 responden laki-laki, ada 19 orang $(47,5 \%)$ yang mengalami obesitas sentral dan 21 orang $(52,5 \%)$ yang tidak mengalami obesitas sentral. Hasil dari uji chi-square menunjukan bahwa terdapat hubungan antara jenis kelamin dengan kejadian obesitas sentral pada usia dewasa $(p=0,001)$ dan responden perempuan berisiko 1,7 kali lebih besar terkena obesitas sentral dibandingkan dengan responden laki-laki. Hasil penelitian ini sejalan dengan penelitian Kusteviani (2015) yang mendapatkan hasil bahwa ada hubungan yang signifikan antara jenis kelamin dengan kejadian obesitas sentral. Hasil tersebut sama dengan hasil penelitian dilapangan yang menunjukan bahwa sebagian besar yang mengalami obesitas sentral adalah responden yang berjenis kelamin perempuan. Tingginya prevalensi obesitas pada perempuan menunjukan bahwa kelebihan

Tabel 2. Hasil Uji Statistik Variabel Bebas dengan Kejadian Obesitas Sentral pada Usia Dewasa di Kelurahan Plalangan, Kecamatan Gunungpati, Kota Semarang Tahun 2017

\begin{tabular}{|c|c|c|c|c|c|c|c|c|c|c|}
\hline \multirow{3}{*}{ No } & \multirow{3}{*}{ Variabel Bebas } & \multicolumn{4}{|c|}{ Kejadian Obesitas Sentral } & \multirow{2}{*}{\multicolumn{2}{|c|}{ Total }} & \multirow{3}{*}{ PR } & \multirow{3}{*}{$95 \% \mathrm{CI}$} & \multirow{3}{*}{$p$ value } \\
\hline & & \multicolumn{2}{|c|}{$\mathrm{Ya}$} & \multicolumn{2}{|c|}{ Tidak } & & & & & \\
\hline & & $\mathrm{n}$ & $\%$ & $\mathrm{n}$ & $\%$ & $\mathrm{n}$ & $\%$ & & & \\
\hline \multirow[t]{3}{*}{1} & Jenis Kelamin & & & & & & & \multirow{3}{*}{1,7} & \multirow{3}{*}{$1,19-2,40$} & \multirow{3}{*}{0,001} \\
\hline & Perempuan & 50 & 80,6 & 12 & 19,4 & 62 & 100,0 & & & \\
\hline & Laki-laki & 19 & 47,5 & 21 & 52,5 & 40 & 100,0 & & & \\
\hline \multirow[t]{3}{*}{2} & Tingkat Pengetahuan & & & & & & & & & \multirow[b]{3}{*}{0,159} \\
\hline & Rendah & 39 & 75,0 & 13 & 25,0 & 52 & 100,0 & \multirow[b]{2}{*}{-} & \multirow[b]{2}{*}{-} & \\
\hline & Tinggi & 30 & 60,0 & 20 & 40,0 & 50 & 100,0 & & & \\
\hline \multirow[t]{3}{*}{3} & Tingkat Pendidikan & & & & & & & & & \\
\hline & Pendidikan dasar & 41 & 78,8 & 11 & 21,2 & 52 & 100,0 & \multirow{2}{*}{1,4} & \multirow{2}{*}{$1,06-1,86$} & \multirow{2}{*}{0,024} \\
\hline & Pendidikan lanjut & 28 & 56,0 & 22 & 44,0 & 50 & 100,0 & & & \\
\hline \multirow[t]{3}{*}{4} & Jenis Pekerjaan & & & & & & & & \multirow[b]{3}{*}{-} & \multirow{3}{*}{0,658} \\
\hline & Tidak bekerja & 19 & 73,1 & 7 & 26,9 & 26 & 100,0 & \multirow[b]{2}{*}{-} & & \\
\hline & Bekerja & 50 & 65,8 & 26 & 34,2 & 76 & 100,0 & & & \\
\hline \multirow[t]{3}{*}{5} & Status Kawin & & & & & & & \multirow{3}{*}{-} & \multirow{3}{*}{-} & \multirow{3}{*}{0,144} \\
\hline & Sudah kawin & 65 & 69,9 & 28 & 31,1 & 93 & 100,0 & & & \\
\hline & Belum kawin & 4 & 44,4 & 5 & 55,6 & 9 & 100,0 & & & \\
\hline 6 & Riwayat Keturunan & & & & & & & & & \\
\hline & Ada & 35 & 85,4 & 6 & 14,6 & 41 & 100,0 & 15 & $18-18-198$ & 0.003 \\
\hline & Tidak ada & 34 & 55,7 & 27 & 44,3 & 61 & 100,0 & 1,5 & $1,18-1,98$ & 0,003 \\
\hline 7 & Aktivitas Fisik & & & & & & & & & \\
\hline & Rendah-sedang & 56 & 84,8 & 10 & 15,2 & 66 & 100,0 & & & \\
\hline & Tinggi & 13 & 36,1 & 23 & 63,9 & 36 & 100,0 & 2,4 & $1,50-3,6 /$ & 0,001 \\
\hline 8 & Status Merokok & & & & & & & & & \\
\hline & Merokok & 20 & 60,6 & 13 & 39,4 & 33 & 100,0 & - & & \\
\hline & Tidak merokok & 49 & 71,0 & 20 & 29,0 & 69 & 100,0 & 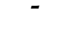 & - & 0,409 \\
\hline 9 & Intake Kalori & & & & & & & & & \\
\hline & Tinggi & 43 & 84,3 & 8 & 15,7 & 51 & 100,0 & 17 & & ○ \\
\hline & Rendah & 26 & 51,0 & 25 & 49,0 & 51 & 100,0 & 1,1 & $1,23-2,22$ & 0,001 \\
\hline
\end{tabular}


lemak pusat lebih banyak terdapat pada perempuan. Menurut penelitian Janghorbani (2007), menyatakan bahwa tingginya prevalensi obesitas sentral terdapat pada perempuan dibandingkan dengan laki- laki karena adanya perbedaan tingkat aktivitas fisik dan asupan energi antara laki-laki dan perempuan. Pada penelitian ini, perempuan lebih banyak memiliki aktivitas fisik ringan-sedang sebanyak 47 orang (75,8\%), sedangkan laki-laki lebih banyak memiliki aktifitas fisik berat sebanyak 21 orang $(52,5 \%)$. Berdasarkan intake kalorinya, perempuan lebih banyak memiliki intake kalori tinggi yaitu sebanyak 32 orang $(51,6 \%)$, sedangkan laki-laki lebih banyak memiliki intake kalori rendah yaitu sebanyak 21 orang $(52,5 \%)$.

Demerath (2007), menyatakan bahwa perempuan secara alami memiliki cadangan lemak tubuh terutama di daerah perut lebih banyak dibandingkan dengan laki-laki. Perempuan cenderung lebih berisiko mengalami obesitas sentral terutama pada saat setelah menopause. . Perempuan postmenopause memiliki persentase lemak perut, kolesterol total, dan trigliserida yang tinggi. Seiring dengan bertambahnya usia dan efek menopause, pada perempuan akan terjadi peningkatan kandungan lemak tubuh, terutama distribusi lemak tubuh pusat.

Hasil penelitian ini sejalan dengan penelitian Veghari dan Howel. Pada penelitian Veghari (2012) terhadap 2471 penduduk dewasa di Iran bagian utara, diketahui bahwa 57,2\% wanita dan 15,8\% laki-laki mengalami obesitas sentral. Hasil penelitian Howel (2012) pada penduduk dewasa usia $>18$ tahun dalam survey nasional Inggris tahun 1993-2008 juga menunjukkan bahwa $35,7 \%$ laki-laki dan perempuan mengalami obesitas sentral.

Berdasarkan hasil penelitian diketahui bahwa dari 52 responden dengan tingkat pengetahuan rendah, ada 39 orang $(75,0 \%)$ mengalami obesitas sentral dan 13 orang $(25,0 \%)$ tidak mengalami obesitas sentral. Sedangkan dari 50 responden dengan tingkat pengetahuan tinggi, ada 30 orang $(60,0 \%)$ mengalami obesitas sentral dan 20 orang (40,0\%) tidak mengalami obesitas sentral. Hasil dari uji chi-square menunjukan bahwa tidak terdapat hubungan antara tingkat pengetahuan dengan kejadian obesitas sentral pada usia dewasa $(p=0,159)$ dan responden dengan tingkat pengetahuan rendah berisiko 1,3 kali lebih besar terkena obesitas sentral dibandingkan dengan responden dengan tingkat pengetahuan tinggi.

Seseorang dengan tingkat pengetahuan yang rendah biasanya akan sering memilih makanan yang asal kenyang saja tanpa mengerti asupan gizi seimbang yang diperlukan oleh tubuh. Sehingga terlalu banyak karbohidrat yang dikonsumsi dalam satu porsi makanan. Seseorang yang memiliki pengetahuan yang baik tentang obesitas, masih saja melakukan perilaku yang tidak sehat seperti gaya hidup sedantery dan makann dalam jumlah yang berlebih ketika mengalami stress. Pengetahuan pada dasarnya merupakan bagian dari perilaku, tetapi hal tersebut tidak menjamin bahwa orang yang memiliki pengetahuan yang baik juga memiliki perilaku yang baik. Karena perilaku seseorang juga dipengaruhi oleh faktor-faktor lainnya. Pada penelitian ini, responden yang memiliki tingkat pengetahuan rendah lebih banyak memiliki intake kalori yaitu sebanyak 27 orang $(51,9 \%)$ dan yang memiliki intake kalori tinggi sebanyak 25 orang $(48,1 \%)$. Sedangkan responden yang memiliki tingkat pengetahuan tinggi lebih banyak memiliki intake kalori tinggi yaitu sebanyak 26 orang $(52,0 \%)$ dan yang memiliki intake kalori rendah sebanyak 24 orang (48,0\%).

Berdasarkan hasil penelitian diketahui bahwa dari 52 responden dengan pendidikan dasar, ada 41 orang $(78,8 \%)$ yang mengamlami obesitas sentral dan 11 orang $(21,2 \%)$ tidak mengalami obesitas sentral. Sedangkan dari 50 responden dengan pendidikan lanjut, ada 28 orang $(56,0 \%)$ mengalami obesitas sentral dan 22 orang $(44,0 \%)$ tidak mengalami obesitas sentral. Hasil dari uji chi-square menunjukan bahwa terdapat hubungan antara tingkat pendidikan dengan kejadian obesitas sentral pada usia dewasa $(p=0,024)$ dan responden dengan tingkat pendidikan dasar berisiko 1,4 kali lebih besar terkena obesitas sentral dibandingkan dengan responden dengan tingkat 
pendidikan lanjut. Hasil penelitian ini sejalan dengan penelitian Kusteviani (2015) yang menyatakan bahwa ada hubungan antara tingkat pendidikan dengan kejadian obesitas sentral. Hasil tersebut sama dengan hasil penelitian dilapangan yang menunjukan bahwa sebagian besar yang mengalami obesitas sentral adalah responden yang memiliki tingkat pendidikan rendah.

Menurut Sudikno (2015) menemukakan bahwa ada hubungan antara tingkat pendidikan dengan kejadian obesitas sentral dengan p-value 0,000 . Tingkat pendidikan mempengaruhi konsumsi pangan melalui cara pemilihan bahan makanan. Orang dengan tingkat pendidikan lebih tinggi akan cenderung memilih bahan makanan yang baik untuk tubuhnya dibandingkan dengan orang yang memiliki tingkat pendidikan lebih rendah.

Berdasarkan hasil penelitian diketahui bahwa dari 26 responden yang tidak bekerja, ada 19 orang $(73,1 \%)$ mengalami obesitas sentral dan 7 orang $(26,9 \%)$ tidak mengalami obesitas sentral. Sedangkan 76 responden yang bekerja, ada 50 orang $(65,8 \%)$ mengalami obesitas sentral dan 26 orang (34,2\%) tidak mengalami obesitas sentral. Hasil uji chi-square menyatakan bahwa tidak ada hubungan antara jenis pekerjaan dengan kejadian obesitas sentral pada usia dewasa $(p=0,658)$ dan responden yang tidak bekerja berisiko 1,1 kali lebih besar terkena obesitas sentral dibandingkan dengan responden yang bekerja. Berdasarkan data Monografi Kelurahan Plalangan tahun 2017, mayoritas responden bekerja sebagai buruh industri sebanyak 875 orang $(41,7 \%)$. Pekerjaan sebagai buruh industri memiliki jam kerja yang panjang, aktivitas fisik rendah dan memiki pola konssumsi yang tidak teratur. Hasil penelitian ini sebagian besar yang mengalami obesitas sentral adalah responden yang bekerja, sedangkan pada penelitian Kusteviani (2015) yang mengalami obesitas sentral terbanyak adalah responden yang tidak bekerja.

Hal ini diduga berkaitan dengan aktivitas fisik yang melibatkan pengeluaran energi. Beberapa pekerjaan melibatkan pengeluaran energi yang tinggi, sementara pekerjaan lain hanya melibatkan sedikit pengeluaran energi. Pada orang yang tidak bekerja atau tidak banyak melakukan aktivitas fisik maka energi yang dikeluarkan akan kebih sedikit apalagi dengan adanya kebiasaan mengonsumsi pangan secara berlebihan maka dapat menimbulkan penumpukan lemak tubuh. Orang yang sifat pekerjaannya terlalu lama duduk dapat meningkatkan kadar kolesterol total dalam darah sebagai akibat adanya penurunan sensitivitas insulin dan enzim yang berfungsi memecah lemak.

Berdasarkan hasil penelitian diketahui bahwa dari 93 responden yang sudah kawin, ada 65 orang $(69,9 \%)$ yang mengalami obesitas sentral dan 28 orang $(31,1 \%)$ tidak mengalami obesitas sentral. Sadangkan dari 9 responden yang belum kawin, ada 4 orang $(44,4 \%)$ mengalami obesitas sentral dan 5 orang $(55,6 \%)$ tidak mengalami obesitas sentral. Hasil uji Fisher menyatakan bahwa tidak ada hubungan antara status kawin dengan kejadian obesitas sentral pada usia dewasa $(p=0,144)$ dan responden yang sudah kawin berisiko 1,6 kali lebih besar terkena obesitas sentral dibandingkan dengan responden yang belum kawin. Tingginya obesitas sentral pada responden yang sudah menikah, hal ini dikarenakan setelah menikah akan cenderung menyesuaian diri dengan pasangannya baik dalam hal gaya hidup maupun pola makanan. Responden yang sudah kawin lebih banyak memiliki intake kalori tinggi yaitu sebanyak 48 orang $(51,6 \%)$. Hasil penelitian ini tidak sejalan dengan penelitian Kusteviani (2015) yang menyatakan bahwa terdapat hubungan antara status menikah dengan kejadian obesitas sentral. pada penelitian ini yang menunjukan bahwa sebagian besar yang mengalami obesitas sentral adalah responden yang sudah menikah. Sedangkan pada penelitian Kusteviani (2015) poporsi obesitas sentral tertinggi pada status cerai dan terrendah pada status belum kawin.

Menurut Janghorbani (2007), tingginya prevalensi obesitas sentral pada status telah menikah. Hal ini dikarenakan kurangnya aktivitas fisik setelah menikah dan perubahan pola makan yang menyesuaikan pasangannya. Penyesuaian ini dapat memengaruhi pola pikir 
dan perubahan gaya hidup seseorang seperti perubahan perilaku makan. Penyesuaian diri dengan pasangan yang buruk mengakibatkan tingginya depresi seseorang. Kondisi stres atau depresi ini dapat menjadikan gaya hidup yang tidak baik seperti konsumsi minuman beralkohol dan konsumsi makanan tinggi lemak. Seseorang yang mengalami depresi cenderung mengonsumsi makanan dalam jumlah yang berlebihan.

Berdasarkan hasil penelitian diketahui bahwa dari 41 responden yang memiliki riwayat keturunan kegemukan, ada 35 orang $(85,4 \%)$ mengalami obesitas sentral dan 6 orang $(14,6 \%)$ tidak mengalami obesitas sentral. Sedangkan dari 61 responden yang tidak memiliki riwayat keturunan kegemukan, ada 34 orang $(55,7 \%)$ mengalami obesitas sentral dan 27 orang $(44,3 \%)$ tidak mengalami obesitas sentral. Hasil uji chi-square diketahui bahwa ada hubungan antara riwayat keturunan dengan kejadian obesitas sentral pada usia dewasa $(p=0,003)$ dan responden yang memiliki riwayat keturunan berisiko 1,5 kali lebih besar terkena obesitas sentral dibandingkan dengan responden yang tidak memiliki riwayat keturunan.

Hasil penelitian ini sejalan dengan penelitian Tchernof dan Despres (2013) yang menyatakan bahwa genetik dapat mempengaruhi tingkat obesitas seseorang. Pada dasarnya manusia memiliki gen yang menentukan peningkatan asam lemak tubuh yang dibutuhkan untuk cadangan, tapi hal ini justru menjadi penyebab timbulnya obesitas. Disamping mengendalikan masa lemak tubuh dan peran gen dalam pemuculan sifat yang berkaitan dengan obesitas mencapai 50\% bahkan lebih. Mekanisme terjadinya obesitas yang merupakan faktor genetik yaitu dalam hal pengendalian adipogenesis. Hal ini juga terbukti dari penelitian tentang orang dewasa yang masa kecilnya diadopsi menemukan bahwa berat badannya mendekati berat badan orang tua biologisnya. Sehingga terlihat bahwa genetik mempengaruhi tingkat obesitas dibandingkan dengan lingkungannya.

Faktor genetik berpengaruh 25\%-75\% terhadap kejadian obesitas sentral. Namun, terdapat faktor lain yang berpengaruh, yaitu pola asuh anak serta adanya interaksi antara gen dengan lingkungan. Selain itu, pada penelitian yang dilakukan oleh Tchernof dan Despres (2013) menyatakan bahwa genetik dapat mempengaruhi tingkat obesitas seseorang. Jika seseorang berasal dari keluarga yang obesitas sentral, maka orang tersebut memiliki kemungkinan mengalami obesitas sentral 2-8 kali dibandingkan berasal dari keluraga yang tidak obesitas (WHO, 2013).

Berdasarkan hasil penelitian diketahui bahwa dari 66 responden dengan aktivitas fisik ringan-sedang, ada 56 orang $(84,8 \%)$ mengalami obesitas sentral dan 10 orang $(15,2 \%)$ tidak mengalami obesitas sentral. Sedangkan dari 36 responden dengan aktivitas fisik berat, ada 13 orang $(36,1 \%)$ yang mengalami obesitas sentral dan 23 orang $(63,9 \%)$ tidak mengalami obesitas sentral. Hasil uji chi-square dapat diketahui bahwa ada hubungan antara aktivitas fisik dengan kejadian obesitas sentral pada usia dewasa $(p=0,000)$ dan responden dengan aktivitas ringan-sedang berisiko 2,4 kali lebih besar terkena obesitas sentral dibandingkan dengan responden dengan aktivitas fisik berat. Hasil analisis tersebut sesuai dengan penelitian yang telah dilakukan oleh Mustelin (2009) yang menemukan bahwa terdapat hubungan yang kuat antara aktivitas fisik dengan lingkar perut. Peningkatan aktivitas fisik lebih berhubungan secara nyata dengan lingkar perut daripada IMT.

Aktivitas fisik ialah setiap pergerakan tubuh yang ditimbulkan oleh otot-otot skeletal dan mengakibatkan pengeluaran energi. Aktivitas fisik/ olehraga yang rutin dapat mendorong penurunan yang cukup besar pada jaringan lemak, bahkan tanpa adanya penurunan berat badan (Tchernof \& Despres, 2013). Hal ini dikarenakan olehraga dapat meningkatkan masa jaringan bebas lemak. Aktivitas fisik merupakan upaya pencegahan peningkatan berat badan dan secara signifikan berkontribusi untuk menurunkan berat badan dalam jangka panjang dan mengurangi risiko kesehatan yang berhubungan dengan penyakit kronis. 
Kurangnya aktivitas fisik dapat menyebabkan zat makanan yang masuk kedalam tubuh tidak dibakar, tetapi hanya ditimbun didalam tubuh sebagai lemak tubuh. $\mathrm{Hal}$ ini sangat berisiko terjadinya berbagai macam penyakit terutama berhubungan dengan kegemukan seperti diabetes mellitus. Aktivitas fisik secara nyata memodifikasi efek dari faktor genetik seseorang. Aktivitas fisik tingkat berat dapat menghindarkan dari meningkatnya penumpukan lemak seiring dengan bertambahnya usia. Latihan (exercise) dapat menurunkan obesitas sentral dengan durani 370 menit/minggu pada laki-laki dan 295 menit/minggu pada perempuan. Pada aktivitas fisik berat lebih dari 30 menit/hari dapat menurunkan 0,91 cm lingkar perut.

Berdasarkan hasil penelitian diketahui bahwa dari 33 responden yang merokok, ada 20 orang $(60,6 \%)$ yang mengalami obesitas sentral dan 13 orang $(39,4 \%)$ tidak mengalami obesitas sentral. Sedangkan dari 69 responden yang tidak merokok, ada 49 orang $(71,0 \%)$ yang mengalami obesitas sentral dan 20 orang $(29,0 \%)$ tidak mengalami obesitas sental. Hasil uji chi-square menunjukan bahwa tidak ada hubungan antara status merokok dengan kejadian obesitas sentral pada usia dewasa $(p=0,409)$ dan responden yang merokok memiliki risiko untuk terkena obesitas sentral 0,9 kali dibandingkan dengan responden yang tidak merokok.

Menurut Chiolero (2008), nikotin meningkatan pengeluaran energi dan menurunkan napsu makan namun perorok berat memiliki berat badan lebih tinggi dibandingkan perokok ringan atau tidak merokok jika diimbangi dengan gaya hidup yang tidak baik. Lebih besarnya berat badan yang tidak merokok dibandingkan yang merokok mungkin diakibatkan terjadinya peningkatan asupan energi dan penurunan pengeluaran energi, aktivitas fisik, perubahan oksidasi lemak, dan metabolisme jaringan adiposa seperti aktivitas lipoprotein. Paparan asap rokok terbukti dapat meningkatkan resisten insulin dan berhubungan dengan akumulasi lemak pusat.
Seseorang yang berhenti merokok akan membuat sensasi makanan bertambah sehingga menyebabkan berat badan meningkat. Selain itu, perokok juga diketahui memiliki rangsangan lapar yang lebih rendah dibandingkan yang tidak merokok. Paparan asap rokok terbukti dapat meningkatkan resisten insulin dan berhubungan dengan akumulasi lemak pusat. Meskipun perokok memiliki rata-rata IMT yang lebih rendah daripada buka perokok, perokok memiliki profil distribusi lemak yang mencerminkan konsekuensi metabolik merokok dengan lebih tingginya lemak pusat.

Sejumlah studi menunjukkan bahwa seseorang yang menghentikan kebiasaan merokoknya kelihatan meningkat berat badannya. Hal ini diduga karena peningkatan asupan energi dan penurunan pengeluaran energi, penurunan aktivitas fisik, perubahan oksidasi lemak, dan metabolisme jaringan adiposa (seperti aktivitas lipoprotein). Lemak visceral dipengaruhi oleh konsentrasi kortisol. Sedangkan perokok memiliki lebih tinggi konsentrasi kortisol plasma daripada orang yang tidak merokok. Tingginya konsentrasi kortisol adalah konsekuensi aktivitas sympathetic nervous system yang diinduksi oleh merokok. Massa lemak visceral meningkat ketika konsentrasi estrogen menurun dan konsentrasi testosterone meningkat. Rendahnya estrogen, kelebihan androgen, dan peningkatan testosteron pada perempuan berhubungan dengan akumulasi lemak visceral. Pada laki-laki lemak visceral meningkat dengan penurunan testosteron. Sementara testosteron pada laki-laki menurun dengan merokok.

Berdasarkan hasil penelitian diketahui bahwa dari 51 responden dengan intake kalori tinggi, ada 43 orang $(84,3 \%)$ mengalami obesitas sentral dan 8 orang $(15,7 \%)$ tidak mengalami obesitas sentral. Sedangkan dari 51 responden dengan intake kalori rendah, ada 26 orang $(51,0 \%)$ mengalami obesitas sentral dan 25 orang $(49,0 \%)$ tidak mengalami obesitas sentral. Hasil uji chi-square menunjukan bahwa ada hubungan antara intake kalori dengan kejadian obesitas sentral pada usia dewasa $(p=0,001)$ dan responden dengan intake kalori tinggi berisiko 
1,7 kali lebih besar terkena obesitas sentral dibandingkan dengan responden dengan intake kalori rendah.

Asupan energi tinggi disebabkan oleh konsumsi makanan sumber energi dan lemak tinggi, sedangkan pengeluaran energi yang rendah disebabkan karena kurangnya aktivitas fisik dan sedentary life style (Riswanti, 2017). Kalori/ energi merupakan hasil dari matabolisme karbohidrat, lemak dan protein. Kelebihan energi disimpan untuk cadangan energi dalam bentuk glikogen sebagai cadangan jangka pendek dan dalam bentuk lemak sebagai cadangan dalam jangka panjang. Kelebihan asupan makanan dapat menimbulkan obesitas khususnya bahan makanan sumber energi, dimana jumlah makanan yang dimakan jauh melebihi kebutuhan tubuh normal. Peningkatan jumlah asupan energi diatas angka kecukupan gizi yang dianjurkan mempengaruhi perkembangan obesitas.

Keseimbangan energi dapat dicapai apabila jumlah energi yang masuk ke dalam tubuh melalui makanan sama dengan jumlah energi yang dikeluarkan. Kelebihan energi yang masuk ke dalam tubuh akan diubah menjadi lemak tubuh, dimana lemak tubuh pada umumnya disimpan dengan pembagian $50 \%$ di jaringan bawah kulit (subkutan), $45 \%$ di sekeliling organ dalam rongga perut dan $5 \%$ di jaringan intramuskuler. Sehingga orang dengan asupan energi lebih memiliki potensi lebih besar untuk mengalami obesitas dibandingkan orang dengan asupan energi cukup. Sebuah penelitian membuktikan bahwa orang dengan asupan energi lebih berisiko mengalami obesitas 1,86 kali lebih besar dibandingkan dengan mereka yang mempunyai asupan energi cukup (Christina \& Ratu, 2011).

\section{PENUTUP}

Berdasarkan hasil penelitian didapatkan kesimpulan bahwa jenis kelamin $(p=0,001)$, tingkat pendidikan $(p=0,024)$, riwayat keturunan $(p=0,003)$, aktivitas fisik $(p=0,000)$, dan intake kalori $(p=0,001)$ berhubungan dengan kejadian obesitas sentral pada usia dewasa.
Sedangkan tingkat pengetahuan $(p=0,159)$, jenis pekerjaan $(p=0,658)$, status merokok $(p=0,409)$, dan status kawin $(p=0,144)$ tidak berhubungan dengan kejadian obesitas sentral pada usia dewasa.

Saran bagi penelitian selanjutnya, diharapkan untuk lebih menggali faktor gaya hidup terhadap obesitas sentral yang masih tidak sesuai dengan teori yang ada dan melakukan pengukuran besar porsi serta kandungan zat gizi makanan yang dikonsumsi responden sehingga diperoleh hasil yang lebih maksimal.

\section{DAFTAR PUSTAKA}

Chaput, J.P. \& Treamblay, A. 2009. Obesity and Physical Inactivity: The Relevance of Reconsidering the Notion of Sedentariness. Obes Facts. 2(4): 249-54

Chiolero, A., Jacot-Sadowski, I., Faeh, D., Paccaud, F. \& Cornuz, J. 2008. Association of cigarettes smoked daily with obesity in a general adult population. Obesity. 15:1311-1318

Christina, D. \& Ratu, A.D.S. 2011. Obesitas pada Pekerja Minyak dan Gas. Jurnal Kesehatan Masyarakat Nasional. 6(3): 104-110

Demerath, E.W., Sun, S.S., Rogers, N., Lee, M., Reed, D., Choh, A.C., Couch, W., Czerwinski, S.A., Churnlea, W.C., Siervogel, R.M., \& Towne, B. 2007. Anatomical Patterning of Visceral Adipose Tissue: Race, Sex, and Age Variation. Obesity. 15: 2984-2993

Erliyani, N. 2012. Kualitas Udara di Lingkungan Kerja, Gaya Hidup, Status Gizi, dan Status Kesehatan Buruh Wanita Pabrik Rokok. Skripsi. Bogor: Institut Pertanian Bogor

Howel, D. 2012. Trends in The Prevalence of Abdominal Obesity and Overweight in English Adults (1993-2008). Obesity Journal. 20(8): 1750-1752

Janghorbani, M., Amini, M., Willett, W.C., Mehdi Gouya, M., Delavari, A., Alikhani, S. \& Mahdavi, A. 2007. First Nationwide Survey of Prevalence of Overweight, Underweight, and Abdominal Obesity in Iranian Adults, Obesity, 15(11): $2797-2808$

Kemenkes RI. 2016. Menkes: Mari Kita Cegah Diabetes dengan Cerdik. Jakarta: Kemenkes RI

Kusteviani, F. 2015. Faktor yang Berhubungan dengan Obesitas Abdominal pada usia 
produktif (15-64 Tahun) di Kota Surabaya. Jurnal Berkala Epidemiologi. 3(1): 45-56.

Listiyana, A.D., Mardiana. \& Prameswari, G.N. 2013. Obesitas Sentral dan Kadar Kolesterol Darah Total. Jurnal Kesehatan Masyarakat, 9(1): 37-43.

Mustelin, L., Silventoinen, K., Pietilainen, K., Rissanen, A. \& Kaprio, J. 2009. Physical Activity Reduces The Influence of Genetic Effects on BMI and Waist Circumference: A Study in Young Adult Twins. Int J Obes, 33(1): 29-36.

Riswanti, I. 2017. Media Buletin dan Seni Mural Sebagai Upaya Meningkatkan Pengetahuan tentang Obesitas. HIGEIA. 1(1): 96-103.
Sudikno, S.H., Dwiriani, C.M. \& Riyadi, H. 2015. Faktor Risiko Obesitas Sentral Pada Orang Dewasa Usia 25-65 Tahun di Indonesia (Analisis Data Riset Kesehatan Dasar 2013). Penelitian Gizi dan Makanan, 38(2): 111-120.

Tchernof, A. \& Despres, J.P. 2013. Pathophysiology of Human Visceral Obesity: An Update. Physiol Rev, 93(1):359-404.

Veghari, G., Sedaghat, M., Banihashem, S., Moharloei, P., Angizeh, A., Tazik, E. \& Moghaddami, A. 2012. The Prevalence and Associated Factors of Central Obesity in Northem Iran. Iranian Cardiovascular Research Journal. 4(4): 164-168.

WHO. 2013. WHO technical report series: Obesity and overweight. Geneva: WHO. 